
VOLUME 10 NOMOR 6 DESEMBER 2021

ISSN : 2303-1514 | E-ISSN : 2598-5949

DOI : http://dx.doi.org/10.33578/jpfkip.v10i6.8296

https://primary.ejournal.unri.ac.id/index.php/JPFKIP

\title{
PEMBENTUKAN KARAKTER BERBASIS KETELADANAN
}

\author{
Ilham Mais ${ }^{1}$, Muhammad Nawir ${ }^{2}$, Hidayah Quraisy ${ }^{3}$ \\ ${ }^{1,3}$ Pendidikan Dasar, Pascasarjana Universitas Muhammadiyah Makassar, Indonesia \\ *Ilhammais11@gmail.com
}

\section{SHAPING THE EXEMPLARY CHARACTERS}

\begin{tabular}{|c|c|}
\hline ARTICLE HISTORY & ABSTRACT \\
\hline $\begin{array}{l}\text { Submitted: } \\
15 \text { Mei } 2021 \\
15^{\text {th }} \text { May } 2021\end{array}$ & $\begin{array}{l}\text { Abstract: The declining condition of character education can be seen from many irregularities } \\
\text { such as corruption, environmental destruction, criminal acts, behavior that violates rules, low- } \\
\text { time discipline, and irresponsible behavior. Thus, shaping the character based on exemplary } \\
\text { and habits is essential to be carried out, especially for students, as a basis for building } \\
\text { civilization. The objective of this study was to identify exemplary-based characters in fifth- } \\
\text { grade students of SD Islam Athirah } 2 \text { Makassar. This study used a qualitative approach with } \\
\text { descriptive findings presentation techniques. Data in this research were collected through } \\
\text { participant observation, in-depth interviews, and documentation analysis. The study results } \\
\text { concluded that the character orders based on exemplary at grade V SD Islam Athirah } 2 \\
\text { Makassar were divided into two. The first was exemplary intentionally, which consisted of } \\
\text { being disciplined to be on time, being responsible, caring for the environment, and caring } \\
\text { socially. The second was an exemplary accident, consisting of exemplary teachers applying the } \\
\text { latest learning technology and courtesy. }\end{array}$ \\
\hline
\end{tabular}

Keywords: character, exemplary, students

Accepted:

10 Oktober 2021

$10^{\text {th }}$ October 2021

\begin{abstract}
Abstrak: Pendidikan karakter yang kian merosot, hal tesebut dapat terlihat dari banyaknya penyimpangan seperti tindak korupsi, perusakan lingkungan hidup, tindak kriminal, perilaku melanggar aturan, ditambah rendahnya disiplin waktu dan perilaku tidak bertanggungjawab. Sehingga, pembentukan karakter berbasis keteladanan dan pembiasaan menjadi penting untuk dilaksanakan khususnya pada murid, sebagai dasar membangun peradaban. Penelitian ini bertujuan untuk mengidentifikasi pembentukan karakter berbasis keteladanan pada murid. Penelitian ini menggunakan pendekatan kualitatif dengan teknik pemaparan temuan secara deskriptif. Teknik pengumpulan data dalam penelitian ini melalui observasi partisipant, wawancara mendalam, dan analisis dokumentasi. Hasil penelitian ini menyimpulkan bahwa pembentukan karakter berbasis keteladanan pada murid kelas V SD Islam Athirah 2 Makassar terbagi menjadi dua, yaitu : Keteladanan secara sengaja, yang terdiri dari: disiplin hadir tepat waktu, bertanggungjawab, peduli lingkungan dengan dan peduli sosial. Keteladanan secara tidak sengaja, yang terdiri dari: keteladanan guru mengaplikasikan teknologi pembelajaran mutakhir, sopan dan santun.
\end{abstract}

Published:

27 Desember 2021

$27^{\text {th }}$ December 2021

Kata Kunci: karakter, pembentukan, murid

\section{CITATION}

Mais. I., Nawir, M., \& Quraisy, H. (2021). Pembentukan Karakter Berbasis Keteladanan. Primary: Jurnal Pendidikan Guru Sekolah Dasar, 10 (6), 1510-1517. DOI: http://dx.doi.org/10.33578/jpfkip.v10i6.8296.

\section{PENDAHULUAN}

Pendidikan karakter penting untuk dilakukan dan diimplementasikan untuk membentuk generasi berkualitas. Pendidikan karakter merupakan salah satu alat untuk membimbing seseorang menjadi baik, sehingga mampu memfilter pengaruh yang tidak baik. Pendidikan karakter bukan hanya penting, tetapi mutlak dilakukan oleh setiap bangsa jika ingin menjadi bangsa yang beradab. Banyak fakta membuktikan bahwa bangsa-bangsa yang maju bukan disebabkan bangsa tersebut memiliki sumber daya alam yang berlimpah, melainkan bangsa yang 
memiliki karakter unggul seperti, kejujuran, kerja keras, tanggung jawab dan lainnya.

Menurut Kementrian Pendidikan dan Kebudayaan, karakter adalah sebagai nilai khas baik (tahu nilai kebaikan, mau berbuat baik, nyata berkehidupan baik, dan berdampak baik terhadap lingkungan) yang terpatri dalam diri dan terejawantahkan dalam perilaku. Pertimbangan di atas juga dalam rangka mewujudkan bangsa yang berbudaya melalui penguatan nilai-nilai religius, jujur, toleran, disiplin, bekerja keras, kreatif, mandiri, demokratis, rasa ingin tahu, semangat kebangsaan, cinta tanah air, menghargai prestasi, komunikatif, cinta damai, gemar membaca, peduli lingkungan, peduli sosial, dan bertanggung jawab, pemerintah memandang perlu penguatan pendidikan karakter. Atas dasar pertimbangan tersebut, pada tanggal 6 September 2017, Presiden Joko Widodo telah menandatangani Peraturan
Presiden (Perpres) Nomor: 87 Tahun 2017 tentang Penguatan Pendidikan Karakter.

Dan juga Undang-Undang nomor 20 tahun 2003 pasal 3 menjelaskan tujuan pendidikan nasional adalah untuk berkembangnya potensi murid agar menjadi manusia yang beriman dan bertakwa kepada Tuhan Yang Maha Esa, berakhlak mulia, sehat, berilmu, cakap, kreatif, mandiri dan menjadi warga negara yang demokratis serta tanggung jawab.

Menurut Ramli (2003), pendidikan karakter adalah pendidikan yang mengedepankan esensi dan makna terhadap moral dan akhlak sehingga hal tersebut akan mampu membentuk pribadi murid yang baik. Dengan demikian maka pendidikan karakter menitikberatkan pada moral/etika yang dicontohkan oleh guru. Guru harus menjadi suri teladan bagi muridnya. Hal ini sesuai dengan Firman Allah SWT dalam Al-Qur'an Surah Al-Ahzab ayat 21, berikut ini :

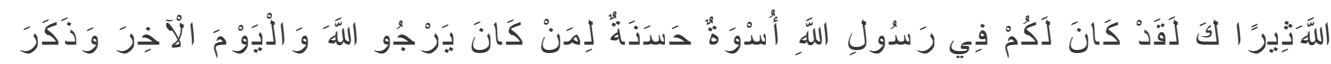

Terjemahannya: "Sesungguhnya telah ada pada (diri) Rasulullah itu suri teladan yang baik bagimu (yaitu) bagi orang yang mengharap (rahmat) Allah dan (kedatangan) hari kiamat dan dia banyak menyebut Allah" (Q.S.Al-Ahzab : 21).

Dalam ayat ini jelas menyeru manusia untuk mencontoh perilaku Rasulullah dalam kehidupan sehari-hari. Metode keteladanan dalam pembentukan karakter dianggap berhasil membentuk karakter murid. Untuk itu, pembetukan karakter melalui keteladanan perlu dikaji secara mendalam. Pendidikan karakter yang ditanamkan dalam pembelajaran dapat mencerminkan citra manusia Indonesia yang bermartabat. Sebagaimana pendidikan karakter berbasis keteladanan dan pembiasaan di sekolah yang saat ini membangun kecerdasan intelektual berusaha menggait kembali pendidikan perilaku yang diterapkan secara terus menerus agar menjadi kebiasaan baik yang harus diperjuangkan sampai menghasilkan budaya karakter manusiawi yang paham dan sadar akan dirinya sendiri dan bertanggung jawab terhadap lingkungan sosial.

\section{METODE PENELITIAN}

Jenis penelitian ini adalah penelitian lapangan (field research) yang bersifat kualitatif dengan menggunakan analisis deskriptif. Moleong (1996:3) menjelaskan bahwa metode kualitatif adalah prosedur penenlitian yang menghasilkan data deskriptif berupa kata-kata tertulis atau lisan dari orangorang dan perilaku yang diamati.

Penelitian ini disebut penelitian kualitatif karena sumber data utama yang diperoleh dari penelitian ini berupa kata-kata atau tindakan dari orang yang diwawancarai, pengamatan/observasi, dan pemanfaatan dokumnetasi yang berkaitan dengan penelitian 
yang penulis bahas yakni mengenai pembentukan karakter berbasis keteladan pada murid kelas V SD Islam Athirah 2 Makassar.

Penentuan subjek adalah suatu cara menentukan sumber dimana penulis mendapatkan data. Dalam penelitian ini penulis menggunakan Purposive Sampling yaitu orang-orang yang terpilih yang akan diberi pertanyaan-pertanyaan menurut ciri-ciri spesifik yang dimiliki sampel itu (Nasution, 1998:8). Penentuan informan dilakukan dengan pengambilan sampel sumber data dengan pertimbangan dan tujuan tertentu. Pertimbangan tertentu yang dimaksud adalah memilih orang yang dianggap paling tahu tentang apa yang diharapkan. Proses pengumpulan data observasi partisipan, wawancara mendalam, studi dokumnetasi, dan gabungan antar ketiganya atau triangulasi data.

\section{TeknikPengumpulan Data}

Untuk memperoleh data yang diperluhkan dalam penelitian ini, ada beberapa teknik yang peneliti gunakan yaitu:

\section{Observasi}

Menurut Suharsimi Arikunto (1989:80) observasi disebut juga dengan pengamatan menggunakan seluruh panca indra. Pengamatan terhadap peristiwaperistiwa itu dilakukan dengan melihat, mendengar, merasakan yang kemudian dicatat seobyektif mungkin. Dalam penelitian ini peneliti berperan sebagai pengamat yang berpartisipasi secara penuh, yakni berperan aktif bersama orang yang diteliti. Peneliti melakukan observasi partisipan dengan cara mengamati bahkan terlibat langsung dalam berbagai aktivitas pendidikan guna mencermati gejala-gejala yang ada dan dimiliki informan sesuai data yang dibutuhkan peneliti pada penelitian.

2. Wawancara Mendalam

Metode wawancara mendalam

(Indepeth Interview) digunakan peneliti untuk mendapatkan informasi yang mendalam dan dapat dipertanggungjawabkan kebenarannya yang berupa informasi terkait dalam pembentukan karakter berbasis keteladanan terkait permasalahan yang diteliti. Wawancara mendalam yang dilakukan dengan mengajukan pertanyaan pada kepala sekolah dan guru tentang sikap murid dan kebijakan yang ada di sekolah terkait pendidikan karakter. Wawancara juga dilakukan pada murid terkait sikap teman sebayanya melalui berbagai pendekatan untuk mencari apa yang peneliti ingin peroleh tanpa terlepas dari berbagai teknik wawancara mendalam untuk menggali semua informasi lebih banyak tentang sekolah tersebut.

3. Dokumnetasi

Dokumentasi menurut Pohan (2007:75) adalah cara pengumpulan informasi yang didapatkan dari dokumen yakni peninggalan tertulis, arsip-arsip yang dimiliki terkait dengan masalah yang diteliti. Metode dokumentasi diperluhkan sebagai metode pendukung untuk pengumpulan data, karena dalam metode ini dapat diperoleh data-data histories. Dokumen yang dimaksudkan dalam sekolah berupa kebijakan yang diatur sekolah, peraturan, data profil sekolah, data guru, data murid, catatan harian. Studi dokumen ini merupakan pelengkap dari penggunaan metode observasi dan wawancara dalam penelitian kualitatif.

4. Triangulasi

Teknik keabsahan data yang digunakan dalam penelitian ini adalah triangulasi data yaitu pendekaran multi-metode yang dilakukan peneliti pada saat mengumpulkan dan menganalisis data (Moelong, 2014:178-179). Dalam penelitian ini peneliti melakukan traingulasi dengan perbandingan sumber dan teori, melakukan pengecekan antar data-data yang didapat dari observasi, wawancara dan juga dokumentasi yang ada.

\section{Teknik Analisa Data}

Teknik analisa data adalah proses penyusunan data agar dapat ditafsirkan dituliskan dalam bentuk kata-kata atau lisan. Inti dari analisis kualitatif adalah ingin 
memahami situasi sosial (obyek) menjadi bagian-bagian, hubungan antar bagian, dan hubungannya dengan keseluruhan (Sugiyono, 2016: 329). Kemudian mengenai proses dari analisis data dilakukan sebelum memasuki lapangan dan selama berada di lapangan. Sebelum memasuki lapangan, peneliti menganalisis data dari hasil studi terdahulu, atau data sekunder yang digunakan untuk menentukan fokus penelitian. Perlu diingat bahwasanya fokus penelitian tersebut bersifat sementara, baru selanjutnya berkembang setelah peneliti masuk dan berada di lapangan.

Selama peneliti berada di lapangan, analisis data yang digunakan adalah analisis data model Miles dan Huberman. Analisis data kualitatif dilakukan secara interaktif dan berlangsung secara terus menerus sampai tuntas, sehingga datanya sudah jenuh (Milles \& Huberman, 1992:16). Data yang terkumpul dari beberapa sumber yang ada di lapangan sebelumnya disajikan terlebiuh dahulu dilakukan proses analisa agar nantinya data tersebut benar-benar dapat dipertanggungjawabkan kebenenarannya.

1. Mereduksi data

Mereduksi data yakni peneliti menelaah kembali seluruh catatan yang diperoleh melalui teknik observasi, wawancara,dokumen-dokumen. Reduksi data adalah kegiatan merangkum data dalam suatu laporan lapangan yang sistematis dan difokuskan pada hal-hal yang inti.

2. Display data,

Display data yakni merangkum hal-hal pokok dan kemudian disusun dalam bentuk deskripsi yang naratif dan sistematis sehingga dapat memudahkan untuk mencari tema sentral sesuai dengan fokus atau rumusan-rumusan unsur-unsur dan mempermudah untuk memberi makna.

3. Verifikasi data

Verifikasi data yakni melakukan pencarian makna dari data yang dikumpulkan secara lebih teliti. Hal ini dilakukan dengan memperoleh suatu kesimpulan yang tepat dan akurat.
Kegiatan ini dilakukan dengan cara mencari pola, bentuk, tema, hubungan, persamaan dan perbedaan, faktor-faktor yang mempengaruhi dan sebagainya. Hasil kegiatan ini adalah kesimpulan hasil evaluasi secara utuh, menyeluruh dan akurat. (Milles \& Huberman,1992:16-19).

\section{HASIL DAN PEMBAHASAN}

Pendidikan karakter adalah suatu sistem penanaman nilai-nilai karakter kepada warga sekolah yang meliputi komponen pengetahuan, kesadaran, atau kemauan, dan tindakan untuk melaksanakan nilai-nilai tersebut (Sofan, 2011:4). Dalam pendidikan karakter di sekolah semua komponen harus dilibatkan, tidak hanya dibebabankan pada satu pihak saja, baik itu pihak dari dalam sekolah maupun dari luar sekolah perlu saling kerjasama. Dari dalam sekolah termasuk kepala sekolah, wakil kepala sekolah, guru, staf tata usaha, petugas kebersihan, securtiy. Di luar sekolah, pada lingkungan rumah ada orang tua dan keluarga terdekat, sementara pada lingkungan masyarakat ada pemerintah dan warga masyarakat. Komponen pendidikan juga tak kalah pentingnya, yaitu isi kurikulum, pengelolaan sekolah, pelaksanaan kegiatan intra kurikuler, ko-kurikuler, ekstrakurikuler.

Praktik penyelenggaraan pendidikan karakter di sekolah pada dasarnya tidak terlepas dari visi misi sekolah. Visi misi dan motto sekolah sebagai landasan dan acuan bagi semua kegiatan proses pembelajaran baik akademik maupun non akademik. Sehingga tercapai tujuan yang dicitakan. Maka dari itu sekolah seharusnya memiliki visi misi dan motto yang berkaitan dengan pendidikan karakter dan dipahami oleh semua pihak yang terlibat, di dalam lebaga pendidikan tersebut, jika tidak maka pembentukan karakter akan sia-sia. Tujuan pendidikan nasional tidak lepas dari terciptanya manusia yang berkarakter atau berakhlak mulia. Sekolah sebagai penyelenggara pendidikan tentunya memiliki 
peran penting dalam membentuk karakter anak bangsa.

Visi misi dan motto sebagai acuan sekolah sangat berkaitan dengan pendidikan karakter, dalam hal ini adalah SD Islam Athirah 2 Makassar dengan visi "Menjadi sekolah unggul yang berciri Islam, berjiwa nasional dan berwawasan global" dan misi "Mengembangkan sistem pembelajaran yang mampu membekali murid dengan kecakapan rasional, kecakapan personal, dan kecakapan sosial". Adapun mottonya "Anggun dalam bersikap dan perilaku yang islami. Unggul dalam mutu dan prestasi, Cerdas dalam sains dan teknologi".

Berdasarkan visi misi dan motto sekolah, maka dapat tergambarkan betapa erat kaitan antara visi misi dan motto dengan pendidikan karakter yang menjadi acuan seluruh warga sekolah menyusun kegiatan sekolah. Pembentukan karakter di sekolah tergantung sejauh mana implementasi visi misi yang berkaitan dengan pendidikan karakter. Seluruh kegiatan pembelajaran baik akademik maupun non akademik, kegiatan intrakurikuler, ko-kurikuler maupun ekstrakurikuler akan bermuara pada pembentukan karakter sebagai perwujudan tercapainya visi misi sekolah. Tentu dengan perencanaan yang matang dari kepala sekolah, guru dan seluruh pihak sekolah yang terkait, kemudian proses pelaksanaan yang disertai evaluasi berkelanjutan maka dapat terbentuk budaya sekolah sebagai pencetak karakter yang kuat.

Dalam pelaksanaannya, pembentukan karakter di sekolah guru mempunyai peranan yang penting dan strategis. Guru merupakan ujung tombak kegiatan sekolah karena langsung berhadapan dengan murid. Guru bisa menjadi model yang diteladani murid. Oleh karena itu, perkataan, tingkah laku, tindakan guru akan memengaruhi murid. Guru perlu menyadari dirinya bukan sekedar mengajar tetapi mendidik. Guru harus berkarakter baik dan mampu menanamkan pendidikan karakter pada murid. Kalau gurunya disiplin, tanggung jawab, peduli lingkungan, peduli sosial, dan lain-lain maka murid akan meniru dan mengidentifikasi karakter baik yang diamati dari gurunya.

Berdasarkan hasil penelitian yang telah dilakukan dan disajikan, maka penulis dapat menjelaskan bahwa pendidikan yang terjadi dalam lingkungan sekolah tidak lepas dari interaksi antara guru dengan murid. Guru memiliki tugas utama sebagai pendidik dan pengajar, sedangkan murid memiliki tugas untuk belajar sebagai bagian dari generasi muda yang akan melanjutkan peradaban hidup manusia. Apabila generasi muda mendapatkan bekal yang baik, maka manfaatnya akan dirasakan bersama. Namun, apabila generasi muda tidak mendapatkan bekal yang baik, maka kita termasuk bagian dari persiapan kehancuran peradaban kehidupan. Oleh karena itu, murid sebagai bagian dari generasi muda saat ini, perlu dipersiapkan dengan sebaikbaiknya dengan pembentukan karakter yang kuat. Dan guru sebagai ujung tombak pendidikan di sekolah karena memiliki kesempatan atau interaksi yang banyak dan berkualitas dengan murid diharapkan dapat memberikan keteladanan yang patut digugu dan ditiru. Semua perkataan, perbuatan tindak tanduk guru akan cenderung ditiru oleh muridnya.

Nasiruddin (2009) menegaskan salah satu proses pembentukan karakter adalah menggunakan keteladanan. Ketaladan merupakan pendukung terbentuknya karakter baik. Keteladanan dapat lebih diterima apabila dicontohkan dari orang terdekat. Misalnya guru menjadi contoh yang baik bagi muridmuridnya atau orang tua menjadi contoh bagi anak-anaknya. Hal ini tak dapat disangkal, karena telah memberikan peran yang sangat signifikan dalam usaha pencapaian keberhasilan pendidikan karakter. Secara psikologis, murid lebih banyak mencontoh perilaku atau sosok figur yang diidolakannya termasuk guru, karena itu seorang pendidik hendaknya menyadari bahwa, perilaku yang 
baik adalah tolak ukur yang menjadi keberhasilan bagi muridnya.

Keteladanan guru dapat diamati murid melalui berbagai interaksi dalam kegiatan pembelajaran di sekolah, baik itu yang dilakukan secara sengaja ataupun tidak disengaja. Keteladanan yang dilakukan secara sengaja adalah pendidik atau guru memberikan contoh yang baik kepada murid supaya dapat ditiru dengan menentukan program atau jadwalnya. Umpamanya, keteladanan guru disiplin hadir tepat waktu di kelas atau saat pembelajaran daring, memakai pakaian yang rapi dan bersih saat menghadapi murid, dan membuka dan menutup pelajaran dengan berdoa, serta mengakhiri pembelajaran juga tepat waktu. Keteladanan yang diberikan guru akan menanamkan karakter disiplin pada murid baik disiplin saat pembelajaran daring maupun masa normal/tatap muka di sekolah. Selanjutnya keteladanan guru peduli (lingkungan dan sosial), misalnya guru saat pembelajaran berlangsung, ketika ada tidak hadir dikarenakan sakit atau tertimpa musibah, guru mengajak murid untuk mendoakan agar murid yang sakit diberikan kesembuhan oleh Allah SWT/diberikan jalan keluar dari masalah yang menimpahnya dan memberikan contoh berbagi kepada yang membutuhkan. Begitupun dengan guru peduli dengan lingkungan, baik kebersihan diri dan tempat mengajar terlebih dahulu dicontohkan oleh guru yang nantinya akan ditiru oleh murid. Keteladanan guru berupa tanggung jawab, misalnya guru bertanggung jawab dengan tugas yang diberikan membawakan materi pelajaran yang dengan sebaik-baiknya.

Adapun keteladanan guru yang tidak disengaja adalah pendidik memberikan contoh yang baik kepada murid terkait dengan perilakunya sebagai individu, tidak direncanakan secara terstruktur atau terjadwal. Jadi pengaruh teladan berjalan secara langsung tanpa disengaja. Dalam hal ini dicontohkan melalui kualitas kepribadian guru sebagai sosok yang diteladani, seperti sopan santun guru dengan berbicara lemah lembut penuh kasih sayang kepada murid saat pelajaran berlangsung maupun diluar jam pelajaran, guru selalu mengucapkan 3 kata ajaib (maaf, tolong dan terimakasih). Guru secara tidak sengaja dapat memberikan keteladanan dengan kualitas keilmuannya ketika bertanggung jawab memberikan materi pelajaran meski masa pandemi dengan mengaplikasikan teknologi informasi yang mutakhir, kemahiran guru mengkolaborasikan berbagai aplikasi-aplikasi pembelajaran seperti Zoom Meetings, Google Suite For Education, Sistem Informasi Pendidikan Sekolah Islam Athirah (SIMDIK Sekolah Islam Athirah), Quizizz, Wordwall, dll.

Bentuk keteladanan secara sengaja dan tidak sengaja yang dilakukan di SD Islam Athirah 2 Makassar tetap dijalankan untuk membentuk karakter murid ditengah-tengah dunia pendidikan dilanda pandemi covid-19, khususnya negara kita tercinta Indonesia. Hal ini tentu tidak lepas juga dari keinginan kuat manajeman Sekolah Islam Athirah untuk tetap memberikan pelayanan terbaik kepada seluruh murid dan orang tua murid yang telah mempercayakan pendidikan putra-putrinya di sekolah ini.

Bentuk keteladanan yang dilakukan secara sengaja dan keteladan tidak secara sengaja ini, senada dengan pendapat Syahidin (2009:157-159) yang menjelaskan bahwa bentuk keteladanan terbagi menjadi dua; Pertama, keteladanan yang tidak disengaja, guru tampil sebagai figur yang dapat memberikan contoh-contoh yang baik. Keberhasilan lebih banyak bergantung pada kualitas kesungguhan realisasi karasteristik guru yang diteladani, seperti kualitas kepemimpinannya, keilmuannya, keikhlasannya, dan sebagainya. Kedua, keteladanan yang disengaja, guru dengan sengaja memberikan contoh yang baik kepada murid supaya mereka dapat menirunya. Contoh, guru sebagai imam ketika sedang sholat berjama'ah di sekolah, membaikkan sholatnya dalam mengerjakan sholat yang sempurna kepada makmunya atau murid. 
Dari penjelasan ahli di atas, menjelaskan bahwa guru memberikan keteladanan yang baik atau contoh yang baik kepada murid sehingga dapat digugu dan ditiru. Keteladanan guru dapat ditiru murid baik yang disengaja maupun yang tidak disengaja oleh guru. Maka dari itu, semua guru harus selalu berhati-hati baik dalam perlakuan, perkataan maupun sikapnya.

Hal ini senada dengan yang yang diungkapkan oleh Puspita (2015) bahwa pembentukan karakter berbasis keteladanan dapat memperoleh hasil yaiut, keteladanan disengaja, yang terdiri dari: keteladanan dalam melaksanakan ibadah, menjaga kebersihan, dan kedisiplinan. Dan keteladanan tidak disengaja, yang terdiri dari: bersikap ramah, sopan dan santun. Berdasarkan paparan tersebut maka pembentukan karakter sangat tepat dilakukan melalui keteladanan baik itu secara sengaja maupun tidak disengaja oleh guru kepada murid.

Oleh karena itu peran guru memberikan keteladanan sangat dibutuhkan. Prasetyo (2019) menyampaikan bahwa pendidikan karakter bagi murid sangat penting untuk segera dilaksanakan di satuan pendidikan. Pelaksanaannya akan lebih efektif apabila guru mampu menempatkan diri sebagai teladan bagi muridnya. Sosok guru yang berkarakter akan memberi efek positif bagi perkembangan karakter murid baik dari tutur kata, sikap, perilaku, penampilan, dan kebiasaan di sekolah maupun di lingkungan masyarakat.

Adapun dasar-dasar keteladanan yang harus dipegang para guru dalam pengalaman keteladanan Suwaid (2006) memberikan penjelasan sebagai berikut : (1) Teladan yang baik, keteladanan yang baik dapat memberikan pengaruh yang besar terhadap jiwa anak, karena anak dapat meniru orang yang lebih dewasa. Rasulullah sendiri mendidik anaknya dengan teladan yang baik sehingga orang tua diharapkan juga agar menjadi teladan yang baik bagi anak-anaknya. Terutama mengenai akhlak kejujuran dalam bergaul dengan anak- anak akan selalu mengawasi perilaku orangorang dewasa dan menirunya. Jika anak-anak mempunyai orang tua yang berlaku jujur, maka mereka akan tumbuh diatas kejujuran dan halhal baik lainnya. (2) Menerapkan keteladanan Nabi, orang tua dan guru dituntut agar memberikan keteladanan yang baik kepada anak-anaknya. Kemampuan anak merespon baik secara sadar maupun tidak sadar sangat tinggi, diluar dugaan karena kita biasanya hanya menganggap anak mereka masih kecil belum paham apa-apa. Oleh sebab itu perlu melaksanakan perintah-perintah Allah dan sunnah Rasulullah sebagai perilaku dan amalan-amalan sunnah.

Dari paparan tersebut, sebaiknya guru memberikan keteladanan dengan meneladani akhlak Nabi dan Rasul Allah SWT. Murid secara tidak sadar akan memiliki akhlak seperti akhlak nabi manakala guru berhasil mentrasfer nilai-nilai tersebut melalui peran yang telah dicontohkan nabi baik yang tertulis di dalam Al-Qur'an maupun Hadist. Maka dari itu sosok guru dalam metode keteladanan di sekolah merupakan peran yang sangat sentral dan utama.

Metode keteladanan dengan memerankan pendidik sebagai teladan bagi muridnya telah sesuai dengan risalah yang dibawakan oleh Rasulullah SAW. Rasulullah SAW, sebagai suri tauladan yang baik selalu mengingat Allah SWT, melaksanakan segala perintahnya dan menjauhi segala larangannya. Sosok teladan juga dapat kita lihat pada Nabi Ibrahim a.s. Dari uraian penjelasan keteladanan tersebut, dari hasil penelitian keteladanan dilakukan untuk membentuk karakter murid agar tujuan pendidikan dapat terealisasikan. Keteladanan dilakukan melalui tindakan agar murid mencontoh, meniru, meneladani perkataan, perbuatan baik dan benar. Keteladanan memberikan pengaruh yang sangat besar dalam pendidikan olehnya itu pendidik hendaknya berperilaku teladan seperti yang dicontohkan oleh Rasullah SAW. Guru merupakan profesi yang mulia, salah satu profesi yang mewarisi tugas para nabi atau 
warasatul anmbiya adalah guru, Allah SWT akan memberikan balasan yang sebaik-baiknya jika tugas ini dapat dijalankan dengan baik yakni amar ma'ruf nahi mungkar artinya mengajak pada kebaikan dan mencegah kemungkaran. Dengan memberikan teladan yang baik maka, akan mengajak manusia untuk berbuat baik dan mencegah kemungkaran merajalela di muka bumi.

\section{SIMPULAN DAN REKOMENDASI}

Setelah membahas berbagai uraian dan penjelasan hasil penelitian lapangan tentang pembentukan karakter berbasis keteladanan maka dapat disimpulkan bahwa pembentukan karakter berbasis keteladanan pada murid kelas V SD Islam Athirah 2 Makassar terbagi menjadi dua, yaitu keteladanan secara sengaja, yang terdiri dari: disiplin hadir tepat waktu, bertanggungjawab, peduli lingkungan dengan dan peduli sosial. Keteladanan secara tidak sengaja, yang terdiri dari: keteladanan guru mengaplikasikan teknologi pembelajaran mutakhir, sopan dan santun.

\section{DAFTAR PUSTAKA}

Al-Qur' an dan Terjemahannya.

Peraturan Presiden Republik Indonesia. "Perpres Nomor 87 Tahun 2017 Tentang Penguatan Pendidikan Karakter" (pasal 1).

Ramli, T. (2003). Pendidikan Moral dalam Keluarga. Grasindo; Jakarta.

Moleong, L. J. (1996). Metode Penelitian Kualitatif. Bandung Rosda Karya.

Nasution, S. (1996). Metode Research:Penelitian Ilmiah. Jakarta: Bumi Karsa.
Suharsimi, A. (1998). Prosedur Penelitian, Suatu Pendekatan Praktek. Jakarta: Rieneka Cipta.

Moleong, L. (2014). Metodologi Penelitian Kualitatif. Edisi Revisi. Bandung: PT

Remaja Rosdakarya.

Pohan, R. (2007). Metodologi Penelitian Pendidikan. Yogyakarta: Ar-Rijal Institut dan Lanarka Publisher.

Sugiyono. (2016). Metode Penelitian Kuantitaitf, Kualitaitf dan $R \& B$. Bandung:PT Alfabet.

Miles, M. B. \& Huberman, A. M. (1992). Analisis Data Kualitatif. Terjemahan oleh Tjetjep Rohendi Rohidi, Jakarta: UI Press.

Sofan. (2011). Implementasi Pendidikan Karakter dalam Pembelajaran. Jakarta: Prestasi Pustakarya.

Nasirudin. (2009). Pendidikan Tasawuf. Semarang: Rasail Media Group.

Puspita, F. (2015). "Pembentukan Karakter Berbasis Pembiasaan dan Keteladanan(Studi Atas Peserta Didik Madrasah Tsanawiyah Negeri I Yogyakarta". Tesis. UIN Sunan Kalijaga.

Prasetyo, D. (2019). Pentingnya Pendidikan Karakter Melalui Keteladanan Guru. https://journal.unnes.ac.id/. Vol 4 No $1(2019)$.

Suwaid, M. (2006). Mendidik Anak Bersama Nabi. Sukoharjo: Pustaka Arafah.

Syahiddin. (2009). Menelusuri Metode Pendidikan dalam Al-Qur'an. Bandung: CV ALVABETA. 